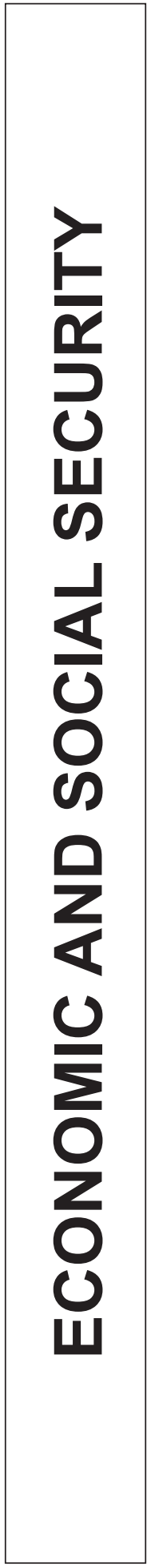





\section{MEGA FTA AS A SIGNAL AGAINST TRADE PROTECTIONISM FOCUSED ON THE EU AND JAPAN FTA}

The global financial crisis in 2008 escalated existing anti globalization sentiments and created views of opposition in liberalized trade resulting from the neo-liberalism. Under this condition, many countries have attempted to curtail imports and impose other restrictions on trade. As a result, the G-20 Leaders Summit, and the meetings of finance ministers and central bank governors agreed to fight against all forms of protectionism in trade and maintain open trade. Despite such a clear political economic statement of the major countries, the World Trade Organization (WTO) addressed its official views on the new trend of increased trade protectionism as a result of deepening global economic crisis.

Despite the recent protectionism on trade, global trade has contributed to rapid economic growth in the world since the second part of $20^{\text {th }}$ century. However, the trade growth has slowed down in the global economy particularly since the global financial crisis in 2008 and the EU's sovereign debt crisis in 2010/2011. In 2016, the growth in the volume of world trade (goods and services) reached only 1.9\% although its forecast was $2.8 \%$. World Trade Organization (WTO) forecasts that the world trade volume was to grow 2.4\% in 2017, while International Monetary Fund (IMF) projected the trade volume growth of $3.8 \%$ in the same year. The global GDP growth will rise $3.4 \%$ in 2018 and it rose $3.1 \%$ last year. It concerns deep uncertainty about near term economic and policy developments that increase the forecast risk owing to the possible trade war between major economies this year (WTO, 2018; IMF, 2018).

Under such a protectionism sentiment, the EU and Japan started their negotiation for the FTA in 2012 and have made a progress to finalize their agreement in Dec. 2017 after 18 rounds negotiations. The two parties had reasons for moving their economic cooperation forward. The EU suffering from the two major economic crises needed to strengthen its economy based on external trade with other part of the world. Japan also needed to redevelop its economy after a long time recession period. Particularly, the Abe Administration has tried to reset the Japanese economy by participating in mega FTAs such as RCEP, TPP, the EU Japan FTA.

Therefore, the two parties agreed in principle on the main elements of the EU-Japan FTA. After the legal verification and translation process, the European Commission is ready to submit the agreement for the approval of the European Parliament and EU member states. As a highly developed economy and a major global trader and investor, 
Japan is one of the most important partners for the EU. The trade relationships between the EU and Japan have been traditionally characterized by large amount of trade surpluses in favor of Japan. However, the trade figures have become much more balanced recent years because the EU can make trade surpluses in services while it still makes trade deficits in goods with Japan.

The EU Japan FTA can create a vast economic cooperation that accounts for approximately 30 percent of global GDP in 2017. Moreover the EU and Japan trade agreement can remove many barriers and support to shape global trade rules in line with high standards of free trade and shared values. In addition, it sends a powerful signal that the two big economies reject protectionism arising since the global financial crisis in 2008 in general and the Trump Administration in 2017 in particular. Accordingly, the EU Japan FTA may impact on the global trade environment positively and could generate another positive trade model for a win-win approach along with the EU Korea FTA that commenced since 2011.

This paper focuses on the EU Japan FTA whether it is a win-win approach or winlose approach. It also investigates and analyzes what are reasons for the two parties to complete the FTA and which industrial sectors can be mostly profited in both parties. Last, but not least it estimates how to impact on the global economy.

\section{THEORETICAL DEBATES}

Most mainstream economists would agree with recent rebuttals to skepticism about the liberal trading order. However, it is the fact that the intellectual and political support for free trade in the USA and elsewhere seems to be weaken, and protectionism starts to be regarded as a wishful thinking for many countries particularly in the USA since the Trump government.

Economic theory suggested comparative advantage and economies of scale would create economic gains through economic efficiency. Therefore, tariffs led to competitive tariff retaliation, which result in a massive shrinkage in foreign trade and low global economic growth. Economic theory never urged that free trade is good for all industries and all people. However, the winners from the free trade can afford to compensate the losers and every one could be made better off because the aggregate gains are positive (O'Rourke, Williamson, 2001; Rosen, 2008).

Economic theory also says that resources will flow to more efficient uses. However, it does not apply when governments and markets do not work well. It shows clear contrast that many East Asian countries soured after a shift to market economics although it is criticized that they profited not from free trade, but from export-led growth and high protectionism. On the contrary, Sub Saharan Africa has generated a low economic growth because its exports are mostly primary products, natural resources, intermediate goods and people. Moreover, bitterness of Latin America about Neo-liberalism focusing on free trade and globalization caused a shift to political left and more state intervention. As a result, there is perception in the South that the global free trade based on the globalization process is unfair that causes poverty instead of wealth (Lawrence, Weinstein, 1999; Ocampo, 2004). 
Even in China, there is a strong policy direction particularly since the global financial crisis to disinterest in further global liberalization and an emphasis on bilateral and politically oriented FTA's in Asia that aims at reducing US influences in the region. Since the global financial crisis, the support for the globalization worldwide has been clearly headed in negative, and it has become dramatically negative particularly in the USA (Hillebrand, et al., 2010; Chicago Council on Global Affairs, 2010a, 2010b).

Samuelson already urged in 1972 that the aggregate gains from trade are not necessarily positive for all nations. He expanded his idea further to claim that growth in the rest of the world can damage a country if it takes place in sectors that compete with its native exports having comparative disadvantage. As a result, relative and even absolute a nation's GDP per capita can fall in such a condition. Gomory and Baumol extended Samuelson's theory and urged that there are many possible equilibria with vastly different outcomes for the countries involved in a modern free trade world. They stated further that it is perfectly possible or rather common for a nation's equilibrium trade outcome to be less than the self sufficiency outcome so that good equilibria are often created rather than bestowed by nature. Accordingly, countries can do much to affect their trading outcomes. Therefore, they urge US protectionism in trade (Samuelson, 2004; Gomory, Baumol, 2009).

However, Bhagwati criticizes that Samuelson's explanation cannot be used as a justification for US protectionism. He also denies Gomory and Baumol's argument because the US could not carry out effective industrial policies to remedy it although their argument is true. Krugman and Obsfeld support Bhagwati's critics that it is an empirical question rather than a fact whether the growth of East Asian countries has actually hurt advanced countries although theoretical possibility still exists (Bhagwati, 2009; Krugman, Obsfeld, 2009).

Economists have developed theoretical models for free trade and estimated welfare gains from reducing or eliminating trade barriers. In line with these models, Krugman, and Broda and Weinstein suggested that trade benefits society through gains overall quality and variety. However this standard static growth from the free trade has left trade promoters quite vulnerable because the static growth models consider only the short run partial equilibrium efficiency gains. At the same time, the static models generate the gains from trade range between 0.5 and 2 percent of GDP that is not impressive (Krugman, 1997; Broda, Weinstein, 2006).

In order to deepen theoretical models finding long term efficiency gains and contribution of free trade to economic growth, economists have developed dynamic models estimating impacts of trade liberalization used by cross country regressions. By using these models, Bradford et al. urged that the US economy in 2005 could be between USD 800 billion and USD 1.4 trillion larger than without post war trade liberalization. However, Acemoglu left the issue of trade and growth undecided because there are models that highlight both positive and negative effects of trade on economic growth so that empirical work must be conducted. Accordingly, Lewer and Van den Berg pointed out that further development of dynamic models and additional empirical research are required. Additionally, linkages between trade and technology as well as trade and institutional quality must be further developed (Bradford, et al., 2006; Acemoglu, 2009; Lewer, Van den Berg, 2007; Feenstra et al., 2009). 
In this paper, it may be wise to adopt the dynamic models rather than static models because the former can explain more precisely why US protectionism has emerged since the global financial crisis and it represents the Trump government trade policy than any other theoretical background. Furthermore, it also provides exposition why the other two major and advanced economies such as the EU and Japan have completed their FTA.

\section{EU'S TRADE POLICY STRATEGY}

\section{Background}

The EU Commission has adapted its trade strategy every few years based on pragmatic approaches since the late 1990s. The EU originally targeted to a policy of managed globalization that aimed to adopt the global rules and strengthen international regimes in order to mitigate anti-globalization protests. In line with this strategy, the EU strongly urged a multilateral trade round in the WTO. Since then, the EU focused on Lisbon Strategy in 2000 aiming to create the EU as the most competitive and dynamic knowledge based economy in the world by 2010 that failed unfortunately. In the part of less ambitious renewed Lisbon Strategy in 2005, the EU realized that trade contributed to economic growth and new job creation.

In the past, the EU had concluded trade agreements mainly for political reasons with neighboring countries and former colonies, while the USA and other nations concluded ambitious bilateral free trade agreements based on competitive liberalization. In 2006, the EU's trade strategy turned to the global Europe that preferred to FTA partners based on market potential, level of protection against EU exports, and negotiations with EU competitors. Currently, the EU implements a new trade strategy since 2015 that is called as Trade for All. It aims mainly to deliver economic growth and new jobs without compromising core principles (Gstöhl, 2016).

\section{Common Trade Policy of the EU}

The EU has carried out its common trade policy since 1970, and all trade activities toward third countries are subordinated to it. The trade policy for global Europe focused on bilateral FTAs and bloc to bloc agreements particularly with the Association of Southeast Asian Nations (ASEAN), the South American Trade Bloc (Mercosur), and the Gulf Cooperation Council. In the bilateral FTAs, the EU envisaged its possible important partners such as India, Japan, Russia, and South Korea. Additionally, the EU also communicated with China to attract the bilateral FTA talk. In fact, the EU regarded China as the single greatest test of Europe's capacity to generate economic growth and employment in the globalization of trade policy. As a result, a far reaching FTA with Korea was signed in 2010 and ratified by the European Parliament. The EU Korea FTA was the first FTA with an Asian country, the first of the new generation of FTA and became the benchmark agreement (de Prado, 2014). 
The global financial crisis and the sovereign debt crisis hit the Europe 2020 Strategy following up on the renewed Lisbon Strategy. The Europe 2020 Strategy aimed at smart, sustainable, and inclusive growth. In this context, the strategy for trade, growth, and world affairs (TGWA) were regarded as an updated of the global Europe strategy since 2010. It emphasized reciprocity particularly in relation to emerging economies that the EU's trade and foreign policies must be mutually reinforcing and encouraging its partners to promote the respect of human rights, labor and environmental standards, sustainable development and investment.

The target partners for TGWA strategy were chosen by large sized economies such as USA, Japan, and Canada, and individual ASEAN member nations were included because the bloc to bloc approach had failed. In early 2010 s, the global trade environment faced protectionism, and global economic condition was still sluggish. Therefore, major economies tired to set up mega FTAs such as Regional Comprehensive Economic Partnership (RCEP), Trans Pacific Partnership (TPP) etc. The EU was no exceptional. It started to talk on Bilateral Investment Agreement (BIA) with China, while the US engaged with TPP. In order to strengthen cross Atlantic economic cooperation, the EU opened the negotiations of Transatlantic Trade and Investment Partnership (TTIP) in 2013. These are all strategic responses to the changing global trade order (Gstöhl, 2016).

In the mid of increasing controversy over TTIP due to the investor to state dispute settlement (ISDS) mechanism and a half way of the Europe 2020 Strategy, the EU presented a new trade strategy called as trade for all in 2015. In the new strategy, the EU demanded more transparency, regulatory issues and dispute settlement in investment and concerns about external effects of FTAs. As a result, it generated higher transparency in TTIP and other negotiations standard practice and extended to trade defense effectively. The EU's strategic focus is to ensure trade agreements delivering concrete benefits to its economy and people that means economic growth and employment in the EU (European Commission, 2017) (See table 1).

Table 1

EU's Trade Policy Strategies from 1990s to 2015

\begin{tabular}{|l|l|l||}
\hline \multicolumn{1}{|c|}{ Period } & \multicolumn{1}{|c|}{ Trade Policy } & \multicolumn{1}{|c|}{ Strategy } \\
\hline 1990s & Multilateral trade round & $\begin{array}{l}\text { Adopt global rules and international } \\
\text { regimes }\end{array}$ \\
\hline 2000-2015 & Bilateral FTAs for global Europe & $\begin{array}{l}\text { Lisbon Strategy and renewed Lisbon } \\
\text { Strategy }\end{array}$ \\
\hline Since 2015 & $\begin{array}{l}\text { Trade and foreign policy mutually reinforced } \\
\text { based on reciprocity: Trade for All }\end{array}$ & Europe 2020 Strategy and TGWA Strategy \\
\hline
\end{tabular}

Source: Author's own adaptation.

In order to make the open trade fair, the EU has used all possible tools to enforce commitments undertaken by FTA concluded partners. It has claimed to remove trade barriers and to prohibit unfair so as to safeguard a level playing field for EU companies. Moreover, the EU enforced its rights through dispute settlement in the WTO whenever it was necessary. As a result, the EU pursued 21 complaints in the WTO with 10 trade partners in 2017 and became the second biggest user of the system along with the 
USA. Additionally, trade defence instruments (TDI) have ensured the EU companies facing unfair competition in the open trade.

The EU works closely between stakeholders such as European Commission, European Parliament (EP), member nations for implementing to enable maximizing opportunities created by FTAs. In fact, around 40 percent of the EU's total exports are covered by FTAs implemented or concluded. Therefore, it is absolutely significant for the EU to manage its FTAs properly in order to generate economic growth and new employment (European Commission, 2017).

\section{EU's Trade with Japan}

The bilateral trade between the EU and Japan has been strengthened since the 1990s. The EU has tied its economic and political relations with Japan after a series of European treaty reforms. As a result, the two economies are already closely interlinked. The Japanese share of total exports to the EU accounted for around 17 percent in 2000, while the EU's share of total exports to Japan was over 5 percent in the same year. These shares declined to 10 percent and nearly 3 percent respectively in 2013. Since then, these had an uprising trend up to over 11 percent and 3 percent respectively in 2016. The reason why their shares of exports declined from 2000 to 2013 in both markets can be explained by the rapid expansion of Chinese exports to the EU and Japan (EPSC, 2017) (See fig. 1).

Figure 1. Share of Respective Total Exports to the EU and Japan (As of 2000-2016, \%)

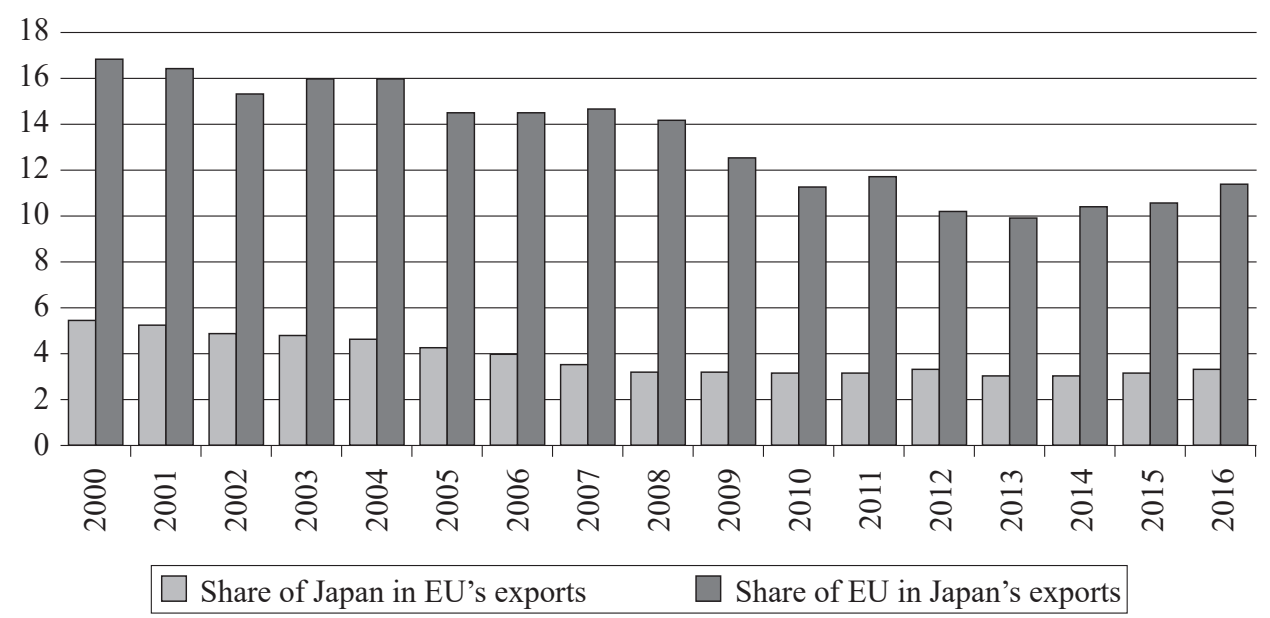

Source: Eurostat, 2017, IMF, 2017.

The EU was the third largest trade partner to Japan after China and USA in 2017, while Japan was the sixth largest trade partner to the EU in the same year. In Asia, Japan was the second largest trade partner to the EU after China, but ahead of South Korea and India. The EU absorbed 11.3 percent of all Japan's exports, while Japan accounted 
for 3.5 percent of the EU's total exports in 2017. Japan was the seventh trade partner to the EU in imports, and its import share accounted for 3.7 percent, while it was the sixth trade partner to the EU in exports, and its export share was 3.2 percent. The EU's total trade with Japan was still far behind its trade total with China. However, their quality of trade goods must be mutually beneficial for the EU and Japan (de Prado, 2014; EPSC, 2017; http://ec.europa.eu/trade/policy/countries-and-regions/countries/ japan/) (See table 2).

Table 2

EU's Top 10 Trade Partners (As of 2017)

\begin{tabular}{|c|c|c|c|c|c|c|c|c|}
\hline \multicolumn{3}{|c|}{ Imports } & \multicolumn{3}{|c|}{ Exports } & \multicolumn{3}{|c|}{ Total trade } \\
\hline Partner & $\begin{array}{l}\text { Value } \\
\text { Mio } €\end{array}$ & $\begin{array}{c}\% \\
\text { Extra- } \\
\text { EU }\end{array}$ & Partner & $\begin{array}{l}\text { Value } \\
\text { Mio } €\end{array}$ & $\begin{array}{c}\% \\
\text { Extra- } \\
\text { EU }\end{array}$ & Partner & $\begin{array}{l}\text { Value } \\
\text { Mio } €\end{array}$ & $\begin{array}{c}\% \\
\text { Extra- } \\
\text { EU }\end{array}$ \\
\hline World & $1,858,257$ & 100.0 & World & $1,879,431$ & 100.0 & World & $3,737,688$ & 100.0 \\
\hline 1. China & 374,823 & 20.2 & 1. USA & 375,845 & 20.0 & 1. USA & 632,021 & 16.9 \\
\hline 2. USA & 256,176 & 13.8 & 2. China & 198,200 & 10.5 & 2. China & 573,023 & 15.3 \\
\hline 3. Russia & 145,094 & 7.8 & $\begin{array}{l}\text { 3. Switzer- } \\
\text { land }\end{array}$ & 150,813 & 8.0 & $\begin{array}{l}\text { 3. Switzer- } \\
\text { land }\end{array}$ & 261,220 & 7.0 \\
\hline $\begin{array}{l}\text { 4. Switzer- } \\
\text { land }\end{array}$ & 110,407 & 5.9 & 4. Russia & 86,186 & 4.6 & 4. Russia & 231,280 & 6.2 \\
\hline 5. Norway & 77,433 & 4.2 & 5. Turkey & 84,490 & 4.5 & 5. Turkey & 154,251 & 4.1 \\
\hline 6. Turkey & 69,760 & 3.8 & 6. Japan & 60,493 & 3.2 & 6. Japan & 129,373 & 3.5 \\
\hline 7. Japan & 68,880 & 3.7 & 7. Norway & 50,702 & 2.7 & 7. Norway & 128,135 & 3.4 \\
\hline $\begin{array}{l}\text { 8. South } \\
\text { Korea }\end{array}$ & 50,017 & 2.7 & $\begin{array}{l}\text { 8. South } \\
\text { Korea }\end{array}$ & 49,805 & 2.7 & $\begin{array}{l}\text { 8. South } \\
\text { Korea }\end{array}$ & 99,822 & 2.7 \\
\hline 9. India & 44,184 & 2.4 & $\begin{array}{l}\text { 9. United } \\
\text { Arab Emi. }\end{array}$ & 42,616 & 2.3 & 9. India & 85,907 & 2.3 \\
\hline 10. Vietnam & 37,018 & 2.0 & 10. India & 41,723 & 2.2 & 10. Canada & 69,182 & 1.9 \\
\hline
\end{tabular}

Source: Eurostat Comext Statistical Regime 4, 2018.

The EU's trade with Japan in goods has made deficit long time that has been chronic. However, its deficit declined continuously till 2013 and started to increase since 2014. The EU's trade with Japan in goods and services has increased from 116.3 billion Euros in 2015 to 129.4 billion Euros in 2017 and from 40.1 billion Euros in 2014 to 49 billion Euros in 2016 respectively. The EU made trade deficit in goods, while it made trade surplus in services. As a whole, the EU made trade surplus with Japan in total owing to the comparative competitiveness in services. In recent years, it is clear that the EU's trade deficit in goods with Japan increased, but its trade surplus in services grew faster than its trade deficit in goods (http://ec.europa.eu/trade/policy/ countries-and-regions/countries/japan/) (See table 2, fig. 2, 3).

Additionally, the FDI in both parties had been in balance a long time. In 2016, the EU's accumulated FDI to Japan accounted for 82.8 billion Euros, while the Japan's accumulated FDI to the EU reached to 205.7 billion Euros in the same year. It means that Japan invested to the EU around 2.5 times more than the EU invested to Japan. 
Figure 2. EU's Trade in Goods with Japan (As of 2015-2017, Billion Euro)

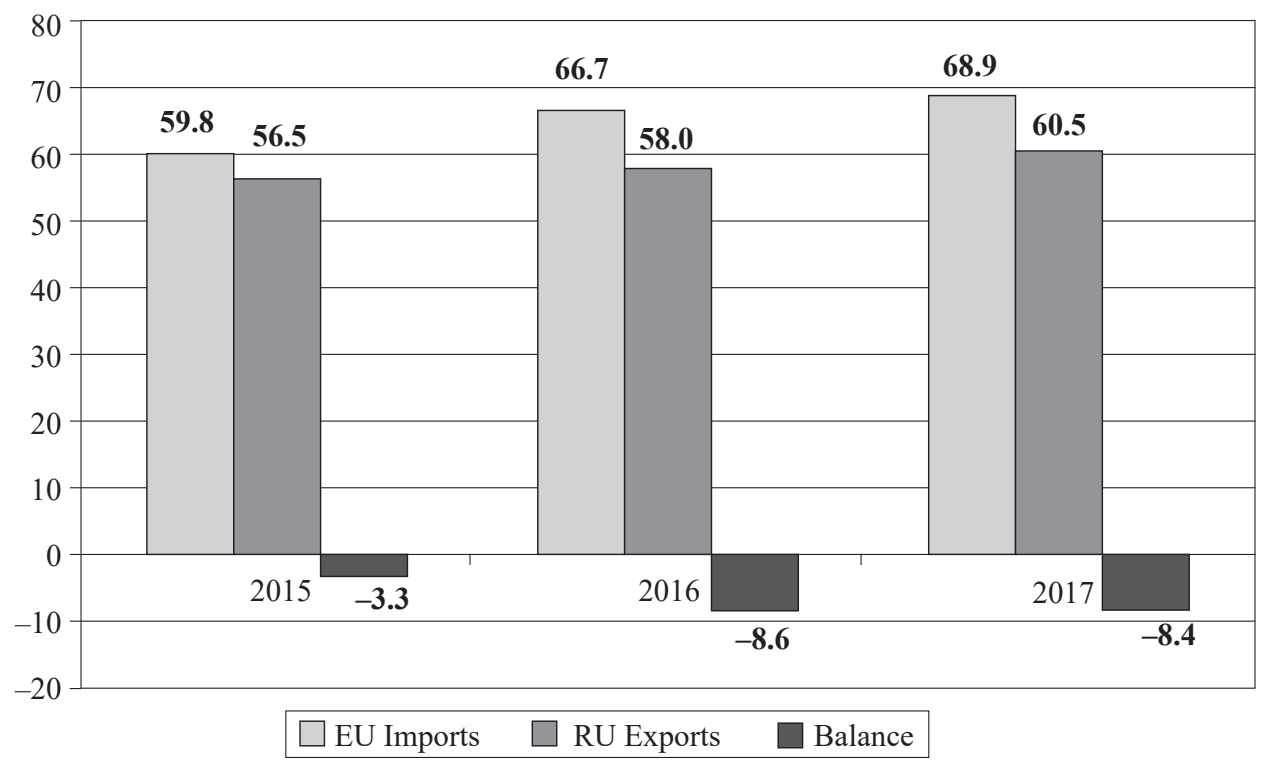

Source: European Commission, 2018, http://ec.europa.eu/trade/policy/countries-and-regions/countries/japan/, May 05, 2018.

Figure 3. EU's Trade in Services with Japan (As of 2015-2017, Billion Euro)

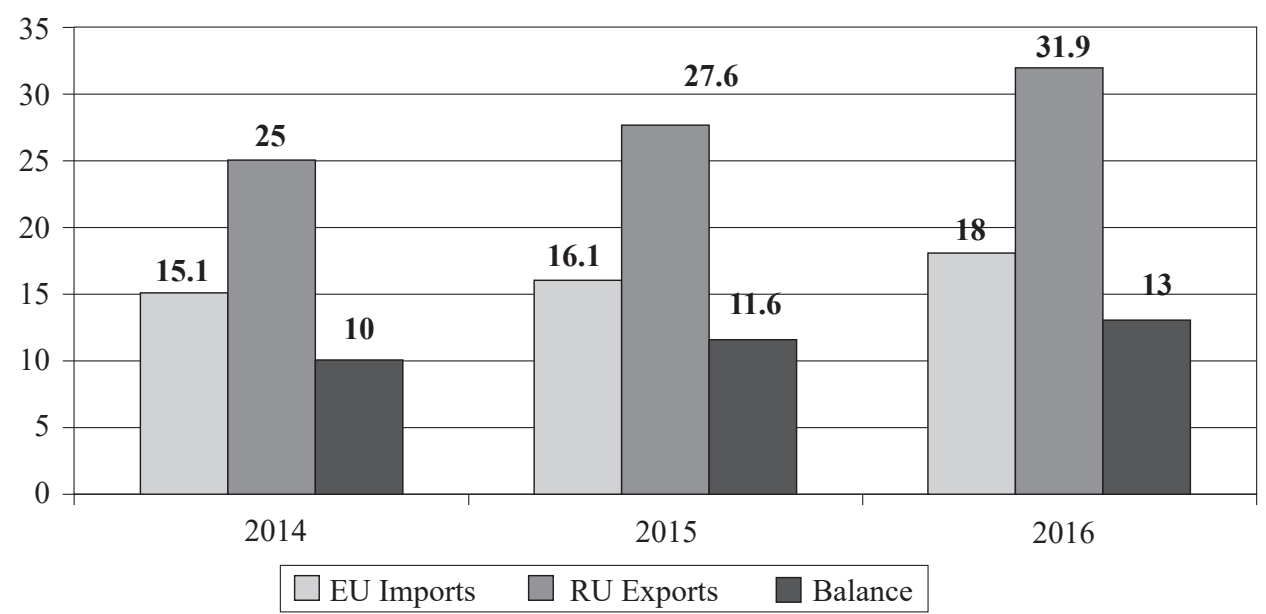

Source: European Commission, 2018, http://ec.europa.eu/trade/policy/countries-and-regions/countries/japan/ (May 05, 2018).

Although the Japanese investment to the EU is higher than the EU's investment to Japan, the EU's investment based on the market size can be regarded as an important destination for the investment (http://ec.europa.eu/trade/policy/countries-and-regions/ countries/japan/) (See fig. 4). 
Figure 4. Foreign Direct Investment (FDI) between the EU and Japan (As of 2016, billion Euros)

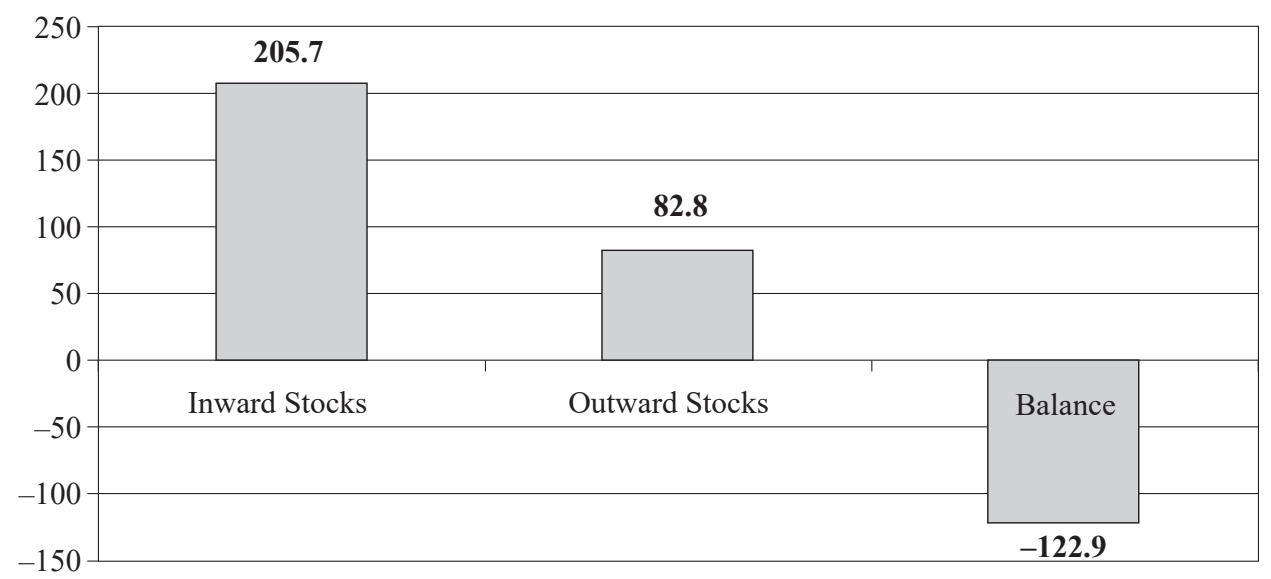

Source: European Commission, 2018, http://ec.europa.eu/trade/policy/countries-and-regions/countries/japan/, May 05, 2018.

\section{JAPAN'S TRADE POLICY STRATEGY}

\section{Background}

Japanese economic policy based on the trade policy had mainly focused on multilateral approach instead of bilateral or regionalism since the Second World War although Japan supported East Asian regionalism because Japanese companies had a significant advantage over their rivals. Until the end of 1990s, Japan preferred the participation of the US in any economic grouping for its trade partners such as APEC, TPP etc. despite her strong economic expansion (Park \& Pasierbiak, 2018).

However, Japanese trade policy started to change along with the Chinese emerging in the East Asian region since 2000. China was particularly active in terms of trading with East Asian countries. When China started to negotiate the FTA with ASEAN, the Japanese trade policy has also changed toward FTAs oriented in the East Asian region. As a result, it focused on trade and FDI for its production bases that resulted in a significant increase of FTAs within the region in the period of 2002-2016. Since then, Japanese trade policy has been implementing bilateral, multilateral, Mega FTAs (Baldwin, 2007, 2011; Park, 2016).

\section{Japanese Trade Policy}

Japan followed its trade policy based on the General Agreement on Tariffs and Trade (GATT) in 1947. Even after the creation of World Trade Organization (WTO) in 1994, 
the Japanese trade policy did not adopt the realities of the world where regional and bilateral trade agreements had become overwhelmed features of the multilateral trading system based on the rules of the WTO. Therefore, Japan rejected any bilateral and regional free trade agreements in favor of non-discriminatory economic cooperation. In line with this perspective, Japan was not in favor to create the Asia Pacific Economic Cooperation (APEC) forum in 1989 due to its open and non-discriminatory liberalization proposal (Sutton, 2005).

Japanese trade policy was against free trade agreements until 1998 because these could possess adverse effects for non member nations. Moreover, these effects could be controlled by abroad through international organizations such as APEC or WTO. In fact, the anti-FTA trade policy supported Japanese agriculture policy resisting liberalization beyond GATT negotiations. Additionally, it also contributed to protecting Japanese companies investing overseas assisted by overseas development assistance (ODA). Japanese trade policy last five decades postwar period focused on accessing to global markets based on the multilateralism. The global market access was a precondition for Japan to acquire low cost capital goods, high technologies, raw materials, and food supplies that could provide industrial success and economic prosperity (Yamamoto, Kikuchi, 1998; Dyrsdale, Armstrong, 2014).

Japanese trade policy changed in the end of the 1990s because strategic, economic, and historic factors were shifted. Particularly after the Asian Financial Crisis in 1997, Japanese trade policy turned from the multilateral regime to the bilateralism in order to secure its regional trade interests that resulted in the high degree of trade and investment integration in the East Asian economy. After the Asian Financial Crisis, Japanese trade policy aimed to revive trade growth through the FTA strategy. It was a significant shift in Japanese trade policy. As a result, the multilateral trading system began to end in favor of preferential trade agreements in 1998 that was not based on debates in policy making circles, but based on Japan and East Asia's quest for stronger institutional ties. Since then, Japan launched its joint study on FTA with South Korea in 1998 and Singapore in 2000 (Dyrsdale, Armstrong, 2014).

Japan and Singapore completed the FTA in 2002. However, its significance was mostly symbolic because of lack of liberalization in tariffs and agricultural sector that aimed to protect Japanese agriculture even in bilateral FTA. Additionally, Japan offered all developing nations negotiating FTAs investment and economic cooperation, while keeping its own agricultural sector largely protected. Similar measures were offered to developed economies that service sectors were excluded for FTA negotiations in order to protect its service sectors. These strategies could not contribute to trade growth because these were not comprehensive enough and had no real economic impact in both parties (Mitsuyo, Fukunari, 2008).

In fact, Japan signaled a strong support for the multilateral system and the most favorable nation (MFN) principle that resulted in proliferation of FTAs among Japanese neighboring countries such as South Korea, China and ASEAN nations. Despite the fact, Japan has launched EPAs under negotiations with South Korea, Mongolia, Canada, the EU etc. However, the impacts of the agreements have been limited because Japanese EPAs have tried to protect its agriculture and services instead 
of promoting to open that limited interests in the partner economies. As a result, Japan could not create any strategic national reform and meet the economic growth goal. Japanese early FTAs were rather politically, diplomatically, and strategically oriented than focused on deliberation of economic costs and benefits (Tatsushi, 2002; Dyrsdale, Armstrong, 2014).

During the 2000s, Japanese government investment in infrastructure in Southeast Asia and South Asia began and contributed to building supply chains and economic development in the region. The primary motivation for the investment was to support Japanese multinational companies (MNCs) in exporting equipment, machinery, and engineering services in the region. However, this trade policy was not connected with domestic reforms that failed to bring South Asia into an integrated East Asian economic system.

Under such a circumstance, the two major economic powers such as USA and China started to build mega FTAs such as RCEP and TPP. ${ }^{1}$ Japan participated in the two mega FTAs actively in order to build the new global trade and economic governance in the Asia Pacific region since the 2010s. However, at the same time, Japan has tried to avoid agricultural reform and services reform while participating in RCEP and TPP. Much of actions can be taken place beyond TPP and RCEP domestically (Dyrsdale, Armstrong, 2014) (See table 3).

Table 3

Japanese Trade Policy Strategies from 1945 to 2018

\begin{tabular}{||l|l|l||}
\hline \hline \multicolumn{1}{|c|}{ Period } & \multicolumn{1}{|c|}{ Trade Policy } & \multicolumn{1}{|c|}{ Strategy } \\
\hline Till 1998 & $\begin{array}{l}\text { Multilateral trade round to access to global } \\
\text { market }\end{array}$ & $\begin{array}{l}\text { Adopt global rules and international regimes } \\
\text { (GATT/WTO) }\end{array}$ \\
\hline $\begin{array}{l}\text { From 1999 to } \\
\text { 2000s }\end{array}$ & Bilateral FTA/EPA for global market & $\begin{array}{l}\text { Protecting agricultural sector from } \\
\text { developing countries and service sector } \\
\text { from developed countries }\end{array}$ \\
\hline Since 2010s & Bilateral and mega FTAs & $\begin{array}{l}\text { Economic growth through trade (Abe- } \\
\text { nomics) }\end{array}$ \\
\hline
\end{tabular}

Source: Author's own adaptation.

\section{Japan's Trade with the EU}

Japan imported goods from the EU over 69.1 billion Euro in 2017 and exported goods to the EU over 68.4 billion Euro in the same year. The EU was the second largest import origin and the third largest export destination for Japan. In total, the EU was the third largest trading partner with over 137.1 billion Euro to Japan. It was after China and USA, but ahead of South Korea. The share of Japanese trade with the EU accounted for 11.3 percent of its total trade share (European Commission, 2018) (See table 4).

${ }^{1}$ TPP became Comprehensive and Progressive Trans Pacific Partnership (CPTPP) in March 2018 under the Japanese leadership because USA announced the official withdrawal from TPP in Jan. 2017. 
Japan's Top 10 trading Partners (As of 2017)

\begin{tabular}{|c|c|c|c|c|c|c|c|c|}
\hline \multicolumn{3}{|c|}{ Imports } & \multicolumn{3}{|c|}{ Exports } & \multicolumn{3}{|c|}{ Total trade } \\
\hline Partner & $\begin{array}{l}\text { Value } \\
\text { Mio } €\end{array}$ & $\begin{array}{c}\% \\
\text { Extra- } \\
\text { EU }\end{array}$ & Partner & $\begin{array}{l}\text { Value } \\
\text { Mio } €\end{array}$ & \begin{tabular}{|c|}
$\%$ \\
Extra- \\
EU
\end{tabular} & Partner & $\begin{array}{l}\text { Value } \\
\text { Mio } €\end{array}$ & $\begin{array}{c}\% \\
\text { Extra- } \\
\text { EU }\end{array}$ \\
\hline World & 594,125 & 100.0 & World & 617,928 & 100.0 & World & $1,212,053$ & 100.0 \\
\hline 1. China & 145,485 & 24.5 & 1. USA & 119,568 & 19.4 & 1. China & 263,053 & 21.7 \\
\hline 2. EU 28 & 69,120 & 11.6 & 2. China & 117,568 & 19.0 & 2. USA & 184,926 & 15.3 \\
\hline 3. USA & 65,359 & 11.0 & 3. EU 28 & 68,412 & 11.1 & 3. EU 28 & 137,532 & 11.3 \\
\hline 4. Australia & 34,509 & 5.8 & $\begin{array}{l}\text { 4. South } \\
\text { Korea }\end{array}$ & 47,191 & 7.6 & $\begin{array}{l}\text { 4. South } \\
\text { Korea }\end{array}$ & 72,078 & 5.9 \\
\hline $\begin{array}{l}\text { 5. South } \\
\text { Korea }\end{array}$ & 24,558 & 4.2 & 5. Tajwan & 35,979 & 5.8 & 5. Tajwan & 58,450 & 4.8 \\
\hline $\begin{array}{l}\text { 6. Saudi } \\
\text { Arabia }\end{array}$ & 24,558 & 4.1 & $\begin{array}{l}\text { 6. Hong } \\
\text { Kong }\end{array}$ & 31,375 & 5.1 & 6. Australia & 48,685 & 4.0 \\
\hline 7. Taiwan & 22,471 & 3.8 & 7. Thailand & 26,058 & 4.2 & 7. Thailand & 46,171 & 3.8 \\
\hline 8. Thailand & 20,114 & 3.4 & 8. Singapore & 20,049 & 3.2 & $\begin{array}{l}\text { 8. Hong } \\
\text { Kong }\end{array}$ & 32,992 & 2.7 \\
\hline $\begin{array}{l}\text { 9. United } \\
\text { Arab Emi. }\end{array}$ & 18,351 & 3.1 & 9. Australia & 14,176 & 2.3 & 9. Vietnam & 29,709 & 2.5 \\
\hline 10. Indonesia & 17,529 & 3.0 & 10. Vietnam & 13,328 & 2.2 & 10. Indonesia & 29,386 & 2.4 \\
\hline
\end{tabular}

Source: IMF, 2018.

Japan exported to the EU mainly machinery and appliances, transport equipment, products of the chemical or allied industries, optical and photographic instruments, and plastics, rubber, and articles that were the top five major export goods to the EU in 2016. These items accounted for 87 percent of the total export. By contrary, Japan imported from the EU mainly products of the chemical or allied industries, machinery and appliances, transport equipment, optical and photographic instruments, and foodstuffs, beverages, and tobacco in the same year. These top five import items accounted for 74.4 percent of the total import (Ministry of Finance, 2017; Ministry of Foreign Affairs, 2017; Deloitte, 2018) (See table 5, 6).

The largest share of Japanese import from the EU was medical products that accounted for 19 percent and the largest share of export was in the category of other machinery with 16.2 percent. Additionally, Japan imported agricultural products including beverages and tobacco that ranked as $5^{\text {th }}$ although domestic agricultural sector was high protected. However, Japan exported agricultural products to the EU with the amount of 66,561 million Euro in 2016, while the EU exported to Japan with the amount of 10,693 million Euro in the same year. In total, Japan was able to protect its agricultural sector effectively although its market size based on GDP approximately one third of the EU market. As a whole, Japan mainly exported to the EU machinery and appliances and transport equipment that accounted for 65 percent of the total export share in the same year, while it imported for the EU mainly chemical or allied industries, machinery and alliances, and transport equipment that was 60.2 percent of the total import share. The structure of the trade between the two parties based on the 
trade items seems to be rather competitive than complementary (Ministry of Foreign Affairs, 2017; Deloitte, 2018).

Japanese Top Five Imports from the EU (As of 2016)

\begin{tabular}{|c|l|c|c||}
\hline \hline Rank & \multicolumn{1}{|c|}{ Products } & $\begin{array}{c}\text { Amount } \\
\text { (Mil. Euro) }\end{array}$ & Share in total (\%) \\
\hline 1 & Chemical or allied industries & 13,835 & 23.8 \\
\hline 2 & Machinery and alliances & 10,693 & 18.4 \\
\hline 3 & Transport equipment & 10,470 & 18.0 \\
\hline 4 & Optical and photographic instruments etc. & 5,425 & 9.4 \\
\hline 5 & Foodstuffs, beverages, tobacco & 2,806 & 4.8 \\
\hline
\end{tabular}

Source: Deloitte, 2018.

The EU was the second largest FDI destination from Japan in 2016 that accounted for 22.5 percent in the total share. This share was behind the USA, but ahead of China and ASEAN combined. However, the EU invested to Japan overwhelmed with the share of 39.6 percent in the same year that was much higher than the US share of 27.4 percent. The total Japanese FDI to the EU aggregated in 2016 was 2.5 times larger than that of EU's FDI to Japan. However, the EU became the largest investor to Japan in 2016 (Bank of Japan, 2016; European Commission, 2018) (Fig. 5, 6).

Figure 5. Japan's Outward FDI (As of 2016, \%)

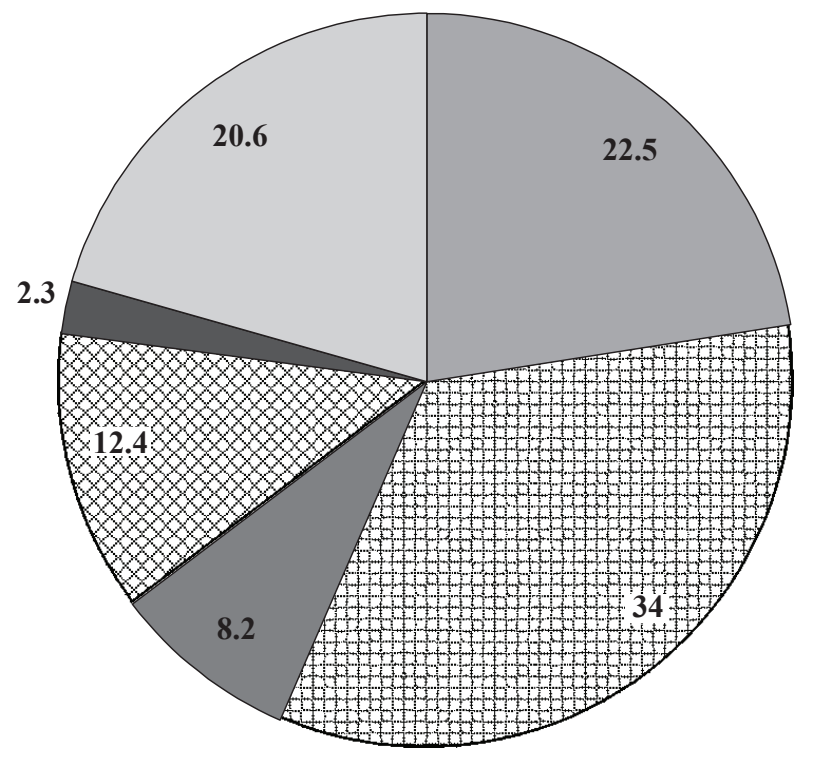

EU

图 USA

$\square$ China

$\otimes$ ASEAN

The Cayman Island

Others

Source: Bank of Japan, 2016. 
Figure 6. Japan's Inward FDI (As of 2016, \%)

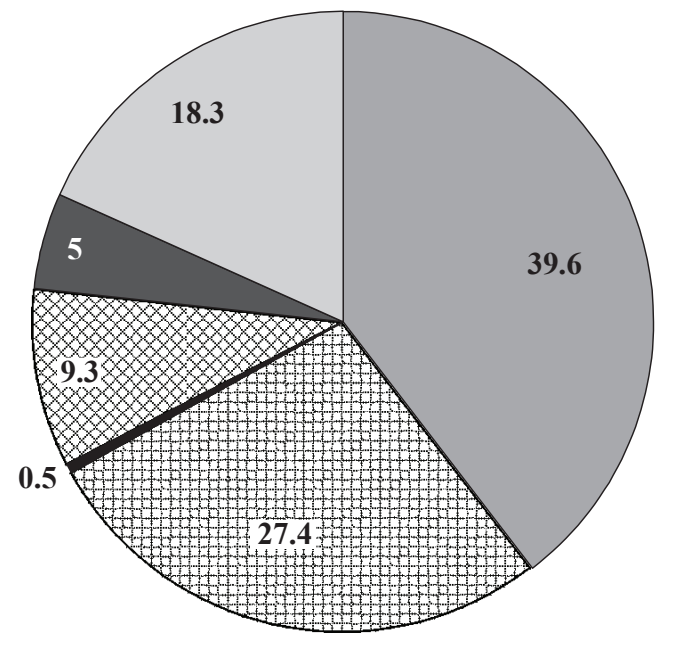

$\square \mathrm{EU}$

固 USA

- China

图 ASEAN

$\square$ The Cayman Island

Others

Source: Bank of Japan, 2016.

\section{ANALYSIS ON EU JAPAN FTA}

\section{Targets for EU Japan FTA}

On July 6 2017, the EU and Japan announced an agreement in principle on a bilateral free trade after 18 rounds of negotiations over four years. The two parties aim to ratify the agreement in early 2019. They characterized the EU Japan FTA as strategically significant and as a strong message for trade liberalization that would affect trade and investment in each party. The EU's GDP accounted for 21.8 percent of the world GDP in 2016, while Japan's GDP reached 6.5 percent in the same year. In total, the two parties' GDP was 28.3 percent of the world GDP. Additionally, they had 638 million populations and trade volume was USD 11,887 billion. These were 8.6 percent and 37.1 percent of the world share respectively (Akhtar, Williams, 2017; Ministry of Foreign Affairs, 2017).

The EU and Japan reached the agreement in principles (AP) on the main elements of the EU Japan FTA that has three main aspects. Firstly, the EU Japan FTA will provide the both parties easy accesses to their markets that will stimulate reciprocal trade and investment activities by forming a vast economic zone accounting for approximately one third of the global economy. Secondly, cooperation between the two parties can be strengthened in the process of establishing various rules, including regulations and standards that can serve as a platform for global issues such as international regulations and standards, global warming etc. Last, but not least, the EU Japan FTA can tackle on protectionism and support the global free trade system as well as restart its trade strategy because the two parties experienced a similar failure on mega trade deals with TTIP and TPP (Sugawara, 2017). 
The EU's main interests in the EU Japan FTA are to eliminate high customs duties particularly in agricultural sector including beverages. The current Japanese tariffs on beef and cheese with nearly 40 percent, chocolate with 30 percent, and wines with 15 percent must be too high for the EU's exporters. Furthermore, the EU is keen to negotiate non tariff measures on automotive, food safety, chemicals etc. with Japan. The EU also targets to open Japanese government procurement.

From the Japanese side, its interests are focused on eliminating high customs duties in automotive, chemicals, electronic devices etc. The current EU's tariffs on these products account for 10 percent, 5.5 percent, and 15 percent respectively. Japan is also keen to change EU's regulatory issues such as non-tariff measures, harmonization and mutual recognition of standards and regulations. The former includes technical barriers to trade (TBT) and the latter are sanitary and phyto-sanitary standards (SPS) and genetically modified organisms (GMOs) (Deloitte, 2018; Business Europe \& Keidanren, 2016; Akhtar, Williams, 2017).

Regarding the elimination of tariffs in both parties, the EU will liberalize 75 percent of its imports from Japan when the EU Japan FTA enters in force and the ratio will rise near 100 percent over 15 years. Japan will also liberalize 91 percent of its imports from the EU, and 99 percent of its imports from the EU will be liberalized over 15 years. The remained 1 percent will be partly liberalized through quotas and tariff reductions. Despite the full tariff elimination, two items such as rice and seaweeds will be excluded from tariff liberalization mutually (Sugawara, 2017).

\section{Impacts of the EU Japan FTA}

Once fully implemented, impacts of the EU Japan FTA will be strong because high tariff lines in the EU and Japan will be eliminated. The EU Japan FTA is described as a deal of cars for cheese because the two parties are keen to generate mutual benefits in their sensitive industrial sectors. The EU eliminates 10 percent of tariff on passenger cars, while Japan removes restrictions on imports of dairy, cheese and other agricultural products. The EU Japan FTA also liberalizes several services sectors such as temporary movement of business personnel, increasing public procurement access etc. (Akhtar, Williams, 2017).

In the automotive sector, EU's imports of automotive products from Japan increased from 9,217 million Euro in 2013 to 13,036 million Euro in 2016, while Japan's imports of automotive products from the EU grew from 7,804 to 8,946 slightly during the same period. The EU's total share of import in automotive products in 2016 accounted for 19.6 percent, while the Japan's share in this sector reached 15.4 percent. It means that Japanese exports of automotive products in the EU market are stronger than that of the EU's in Japanese market. The EU's tariff on passenger cars will decrease over a period of eight years. It will decline from 10 percent to 8.8 percent a year later and to 5 percent four year later after the FTA enters into force (Deloitte, 2018) (Fig. 7).

By removing tariffs on imports of Japanese cars and components, Japan could gain price advantages in its automotive products in the EU market. However, more than 65 percent of all Japanese vehicles sold in the EU market are produced in the EU. 
Japanese car producers maintain 14 production plants and $16 \mathrm{R} \& \mathrm{D}$ centers in the EU. As a result, removing tariffs on automotive products could boost not only Japanese exports to the EU market, but also production and new employment in Japanese owned car plants in the EU.

Figure 7. EU-Japan Trade in Automotive Products between 2013 and 2016 (Mil. Euro)

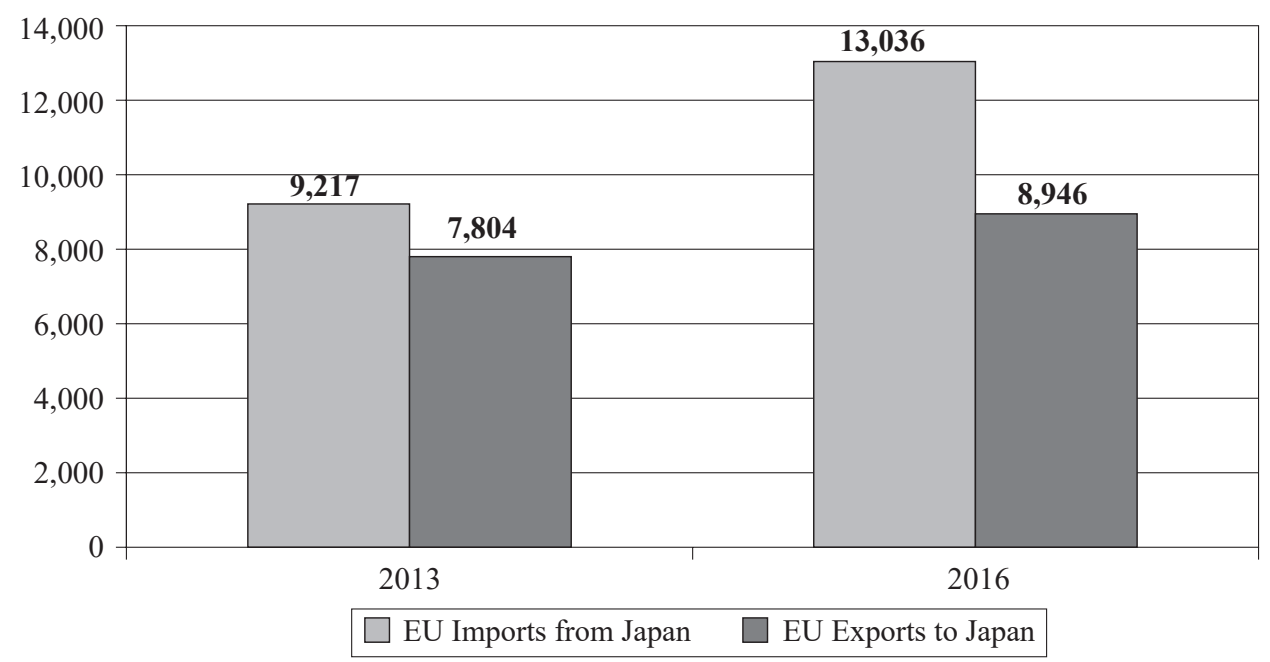

Source: Deloitte, 2018.

In agricultural sector, the pattern of tariff elimination is based on a full or a gradual elimination that is the same as the electronics sector. Chocolate and wine to Japan as well as rice to the EU will be fully eliminated, while the tariff of beef to Japan will be reduced from 40 percent to 9 percent that will be carried out progressively up to 21 years. However, the tariff rate quotas (TRQ's) will be used continuously. The EU Japan FTA will strengthen the standard cooperation in SPS and agricultural safeguard measures (ASMs).

In recent years, the EU's agricultural exports to Japan declined rapidly. Its exports volume declined from 54,016 million Euros in 2013 to 10,693 million Euros in 2016, while its import from Japan increased from 56,620 million Euro to 66,561 million Euro during the same period. Since 2013, the EU's imports of agricultural products from Japan had been five times larger than Japanese imports. Therefore, the EU Japan FTA could boost the EU's exports to Japan because the high tariffs on agricultural products in Japan are planned to be eliminated (Deloitte, 2018; Hilpert, 2017) (Fig. 8).

As a whole, the impact of the EU Japan FTA can be significant. The long term GDP growth for the EU is estimated up to 0.76 percent, while Japanese GDP growth can be added to 0.29 percent. Bilateral exports will increase by 34 percent for the EU and 29 percent for Japan, while the total exports grow four percent for the EU and six percent for Japan. The aggregated GDP growth generated by the EU Japan FTA is larger than that of created by the EU Korea FTA because Japanese economy is over three times larger than South Korean economy. Additionally, the EU's real 
wages for less skilled and skilled labor increase by 0.68 percent and 0.7 percent based on the CGE modeling in the impact assessment. These increase by 0.45 percent and 0.5 percent in Japan (European Commission, 2016).

Given the conservative estimation, the EU Japan FTA can generate total income gains worth about 11 billion Euros to the EU member nations per year, while it could add welfare effects for Japan about nine billion Euros for a period of about ten years. Among the EU member nations, Germany will gain the largest share with 3.4 billion Euros. The next will be the UK with 1.6 billion Euro, France with 1.2 billion Euro, and the Netherlands with 0.9 billion Euro. However, in term of relative gains, the countries with the largest gains are Ireland with 0.19 percent, the Netherlands with 0.14 percent, Luxembourg with 0.13 percent, and Germany with 0.11 percent. Even the EU peripheries such as Greece, Portugal, and Romania would gain smaller than 0.02 percent. As a result, all EU countries are expected to benefit although their relative gains vary that depends on their industrial structure and capacity (Felbermayr et. al., 2017).

Figure 8. EU-Japan Trade in Agricultural Products between 2013 and 2016 (Million Euro)

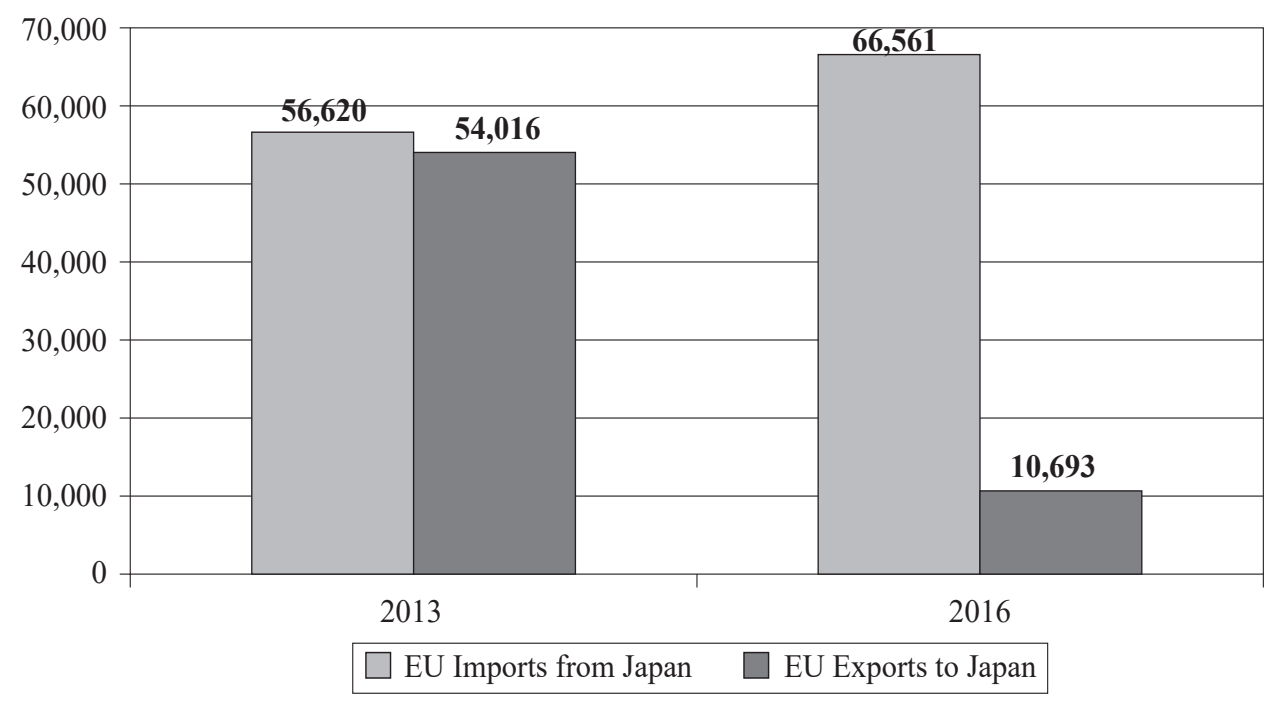

Source: Deloitte, 2018.

\section{Impacts on the global economy}

A key factor to start negotiations for the EU Japan FTA was Japan's reaction to the comprehensive FTA between the EU and South Korea in 2009. It was a significant fact because it provided the EU the possibility to thrive in a traditionally difficult Asian market and South Korea the possibility to export more automotive products, electronics goods, and other industrial products to the EU markets. This put Japanese exporters potentially at a disadvantage (de Prado, 2014). 
The EU Korea FTA came into force in July 2011 and posed specific treats to Japanese businesses trading with the EU in direct competition with South Korean firms particularly in automobile and electronics. It provided South Korean products a momentum to gain competitive advantage through eliminating high tariffs in the EU markets that mobilized the EU and Japan to come up with a similar agreement. EU's exports to Korea increased by 37 percent overall, while its imports from South Korea increased marginally by one percent due to the weak EU's economic growth and shifting production by South Korean firms to the EU countries. Accordingly, the EU Japan FTA may create similar affects (Tyszkiewicz, 2013).

The EU Japan FTA provides Japanese industries new opportunities to gain competitive advantage particularly in computer and electronics, automotive, machinery sectors albeit at a smaller scale. The advantage of automobile sector can be very limited because Japan produces over 65 percent of passenger cars in the ET that are sold in the EU markets. South Korean exports to the EU can be affected by trade diversion effects. However, the direct effects can be relatively minor. The total loss of exports from South Korea, China, and Taiwan to the EU is estimated by 1.5 billion Euros. The EU Japan FTA can generate world income by about 18 billion Euros. The rest of the world would lose about 2 billion Euros. As a result, East Asian economies such as South Korea, China, and Taiwan would be the largest part of the loss, but still very minor (Felbermayr et. al., 2017; Deloitte, 2018).

***

The European Commission has produced strategy papers last two decades that aims mainly at economic growth and employment particularly in the Lisbon Strategy of 2000 and the current Europe 2020. Additionally, it also focuses on different parts of the world including Asia since the 1990s. However, its vision is constrained by the power of the European Commission, which is high mainly in trade and aid, but still limited in other issues.

In Japan, its strategic goals since the 1950s were to support the country to thrive under its core alliance with the U.S. that contains recently high risk because a new global power structure based on multi polarized has been formed. Therefore, it is needed to galvanize public and semi public institutions into a more clear strategy.

Additionally, the EU had been hit by two major economic crises such as the global financial crisis and the sovereign debt crisis that resulted in low economic growth and high unemployment. In order to overcome these economic crises, the EU needed to boost its trade that generates economic growth and new employment. In line with this strategy, the EU set the target to complete mega FTAs such as the EU Japan FTA and TTIP.

In Japan, the economic situation was rather similar due to the global financial crisis, and long time recession that generated low economic growth. Since the Abe government took the power in Dec. 2012, it launched new economic policy based on bold monetary policy, flexible financial policy, and a growth policy that must revitalize Japanese stagnant economy. Similar to the EU, Japan turned its trade policy to the mega FTA strategy that launched the EU Japan FTA and TTP. 
Since 2012 the EU and Japan had 18 rounds of negotiation and finally completed their agreement in principles for the EU Japan FTA in July 2017. The two parties agreed to eliminate tariffs and rationalize non tariff barriers although certain products such as rice and beef can be protected continuously. Despite such barriers, the EU can export more agricultural products to Japan, while Japan can export more machinery, automotive, electronics products to the EU.

Overall the EU Japan FTA can generate about 0.76 percent GDP growth to the EU and about 0.29 percent GDP growth to Japan additionally per year next ten years long. Furthermore, it also creates new employment in both parties. Although the EU Japan FTA can create some looser particularly in East Asian economies such as South Korea, China, and Taiwan, their total amount is estimated as very low. In the global economy, the EU Japan FTA can generate much larger gains than lost. As a result, it is not only a win-win approach for the EU and Japan, but also for the whole global economy if it enters into force.

\section{REFERENCES}

Acemoglu D. (2009), Modern Economic Growth, Princeton University Press, Princeton, NJ.

Akhtar S. I., Williams B. R. (2017), The Proposed EU Japan FTA and Implications for U.S. Trade Policy, July 14, (IN 10738) CRS Insight, https://fas.org/sgp/crs/row/IN10738.pdf (10.05.2018).

Baldwin R. (2007), Managing the Noodle Bowl: The Fragility of East Asian Regionalism, ADB Working Paper Series on Regional Economic Integration, No. 7, pp. 1-31.

Baldwin R. (2011), Sequencing Regionalism: Theory, European Practice, and Lesson for Asia, ADB Working Paper Series on Regional Economic Integration, No. 80, pp. 1-71.

Bank of Japan (BOJ) (2016), Japan's Balance of Payments Statistics and International Investment Position for 2016, https://www.boj.or.jp/en/statistics/br/bop_06/bop2016a.pdf (10 May 2018).

Bhagwati Jagdish (2009), Does the U.S Need a New Trade Policy?, "Journal of Policy Modeling", Vol. 31, No. 4, pp. 509-514.

Bradford S., Greico P., Hufbauer G. C. (2006), The Payoff to America from Globalisation, "The World Economy", Vol. 29, No. 7, pp. 893-917.

Broda C., Weinstein D. E. (2006), Globalization and the Gains from Variety, "The Quarterly Journal of Economics", Vol. 121, No. 2, pp. 541-585.

Business Europe and Keidanren (2016), Joint Statement for EU-Japan Regulatory Cooperation, 13 Dec. https://www.businesseurope.eu/sites/buseur/files/media/position_papers/rex/ 2016-12-13_be-keidanren_statement_on_eu-jap_regulatory_cooperation.pdf (11.05.2018).

Chicago Council on Global Affairs (2010a), Global Views 2010, CCFR, Chicago, IL.

Chicago Council on Global Affairs (2010b), Global Views 2010: Detailed Findings, CCFR, Chicago, IL.

Deloitte (2018), The New EU Japan EPA: How Can your Company Leverage Improved Trade Cooperation and Market Access?, Belgium: Delotte.

De Prado C. (2014), Prospects for the EU-Japan Strategic Partnership: A Global Multilevel and SWOT Analysis, European University Institute, Florence-Tokyo. 
Dyrsdale P., Armstrong S. (2014), Japan's Foreign Economic Policy Strategies and Economic Performance, Working Paper Series, No. 340, Center on Japanese Economy and Business, Columbia University, www.gsb.columbia.edu/cjeb/research (06.05.2018).

European Commission (2016), Trade Sustainability Impact Assessment of the Free Trade Agreement between the European Union and Japan: Final Report, http://trade.ec.europa.eu/doclib/ docs/2016/may/tradoc_154522.pdf(12.05.2018).

European Commission (2017), Report on the Implementation of the Trade Policy Strategy Trade for All: Delivering a Progressive Trade Policy to Harness Globalisation, COM (2017) 491 final, EC, Brussels.

European Commission (2018), European Union, Trade in Goods with Japan, http://trade.ec.europa. eu/doclib/docs/2006/september/tradoc_113403.pdf (08.05.2018).

European Political Strategy Centre (EPSC) (2017), EU-Japan: Advanced Economies Shaping the Next Stage of Inclusive Globalisation, EPSC Brief, July 06, European Commission, Brussels.

Feenstra R. C., Mandel B. R., Reinsdorf M. B., Slaughter M. (2009), Effects of Terms of Trade Gains and Tariff Changes on the Measurement of U.S. Productivity Growth, NBER Working Paper No. 15592.

Felbermayr G., Kimura F., Okubo T., Steininger M., Yalcin E. (2017), On the Economics of an EUJapan Free Trade Agreement, ifo Forschungsberichte 86, ifo Institute, Berlin.

Gomory R., Baumol W. (2009), Globalization: Country and Company Interests in Conflict, "Journal of Policy Modeling", Vol. 31, No. 4, pp. 540-555.

Gstöhl S. (2016), Trade for All - All for Trade? The EU's New Strategy, College of Europe Policy Brief, Jan. http://aei.pitt.edu/93101/1/gstohl_cepob_3-16.pdf (3.05.2018).

Hillebrand E. E., Lewer J. J., Zagardo J. T. (2010), Backtracking from Globalization, "Global Economy Journal", Vol. 10, No. 4, pp. 1-17.

Hilpert H. G. (2017), The Japan-EU Economic Partnership Agreement, SWP Comments 49, Nov., German Institute for International and Security Affairs, Berlin.

International Monetary Fund (IMF) (2017), World Economic Outlook Database, Nov. 21, IMF, Washington D.C.

International Monetary Fund (IMF) (2018), World Economic Outlook Update, July, 16, IMF, Washington D.C.

Krugman P. R. (1979), Increasing Returns, Monopolistic Competition, and International Trade, "Journal of International Economics", Vol. 9, No. 4, pp. 469-479.

Krugman P. R., Obstfeld M. (2009), International Economics, Pearson, Addison-Wesley, Boston, MA.

Lewer J. J., Van den Berg H. (2007), International Trade and Economic Growth, M.E. Sharpe, Armonk, NY.

Ministry of Finance (MOFI) (2017), Trade Statistics of Japan, http://www.customs.go.jp/toukei/info/ tsdl_e.htm (09.05.2018).

Ministry of Foreign Affairs (MOFA) (2017) Japan EU EPA, http://www.mofa.go.jp/files/000013835. pdf (09.05.2018).

Mitsuyo A., Fukunari K. (2008), Japanese FTA/EPA Strategies and Agricultural Protection, "Kei Business Review", Vol. 44, pp. 1-25.

Ocampo J. A. (2004), Latin America's Growth and Equity Frustration During Structural Reforms, "Journal of Economic Perspectives", Vol. 18, No. 2, pp. 67-88.

O'Rourke K. H., Williamson J. G. (2001), Globalization and History: The Evolution of Nineteenth Century Atlantic Economy, The MIT Press, MA, Cambridge. 
Park S.-C. (2017), Can Trade Help Overcome Economic Crisis? Implications for Northeast Asia Creating Regional FTA between Korea, China, and Japan and Mega FTAs such as RCEP and TPP, "International Organizations Research Journal”, Vol. 12, No. 2, pp. 104-128.

Park S.-C., Pasierbiak P. (2018), Japan's Role in East Asian Economic Regionalism, "Institutions and Economies", Vol. 10, No. 2, pp. 121-145.

Rosen H. (2008), Strengthening Trade Adjustment Assistance, Peterson Institute for International Economics Policy Brief, PD 09-2, January, Washington D.C.

Samuelson P. (2004), Where Richardo and Mill Rebut and Confirm Arguments of Mainstream Economists Supporting Globalization, "Journal of Economic Perspectives", Vol. 18, No. 3, pp. 135-146.

Sugawara J. (2017), Significance of the Japan-EU EPA: The Agreement in Principle, Restart of Japan's Trade Strategy, July 12, https://www.mizuho-ri.co.jp/publication/research/pdf/eo/ MEA170814.pdf (11.05.2018).

Sutton M. (2005), Japanese Trade Policy and Economic Partnership Agreements: A New Conventional Wisdom, "Ritsumeikan Annual Review of International Studies", Vol. 4, pp. 113-135.

Tatsushi O. (2002), An Approach towards Japan's FTA Policy, Working Paper Series 01/02, No. 4, IDE APEC Study Center, Tokyo.

Tyszkiewicz R. (2013), Towards New Political and Economic Agreements with Japan: Bringing New Dynamism into the Strategic Partnership between the EU and Japan, Polish Institute of International Affairs, Policy Paper, No. 9 (57) April, pp. 1-7, Warsaw.

Yamamoto Y., Kikuchi T. (1998), Japan's Approach to APEC and Regime Creation in the Asia Pacific, in: Asia Pacific Crossroads: Regime Creation and the Future of APEC, (eds.) V. K. Aggarwal, C. E. Morrison, St Martins Press, New York.

World Bank (2017), World Development Indicators, Nov. 21, Washington D.C.

World Trade Organization (WTO) (2018), Annual Report 2018, Geneva.

\begin{abstract}
The research questions of the paper are whether the EU Japan FTA can be a win-win approach or win-lose approach? Moreover what are reasons for the two parties to complete the FTA and which industrial sectors can be mostly profited in both parties? Last, but not least how to estimate impacts on the global economy? The hypotheses are FTA can reduce trade protectionism, and the former can generate more economic benefits to the participating countries than latter in the long term based on the trade dynamic group. The research methodology is to use cross sectional analysis based on statistic data and information collection as well as trade policy analysis. Additionally, critical analysis of literature and inference analysis are employed.

The conclusion of the research is that the EU Japan FTA can generate about 0.76 percent GDP growth to the EU and about 0.29 percent GDP growth to Japan additionally per year next ten years long. Furthermore, it also creates new employment in both parties. Although the EU Japan FTA can create some looser particularly in East Asian economies such as South Korea, China, and Taiwan, their total amount is estimated as very low. In the global economy, the EU Japan FTA can generate much larger gains than lost. As a result, it is not only a win-win approach for the EU and Japan, but also for the whole global economy if it enters into force.
\end{abstract}

Keywords: Mega FTA, trade barriers, global trade rule, free trade, protectionism 


\section{MEGA-REGIONALNA UMOWA O WOLNYM HANDLU JAKO SPRZECIW WOBEC PROTEKCJONIZMU HANDLOWEMU NA PRZYKŁADZIE UMOWY O WOLNYM HANDLU MIĘDZY UE I JAPONIĄ}

\section{STRESZCZENIE}

Pytania badawcze omawiane w tym artykule dotyczą tego, czy umowa o wolnym handlu UE z Japonią może być rozwiązaniem korzystnym dla obu stron, czy też wygrana jednej strony oznacza przegraną drugiej, a także analizuje powody, dla których obie strony zawierają umowę o wolnym handlu i które gałęzie przemysłu w obu krajach mogą na niej najwięcej skorzystać. Ostatnią kwestią jest to, jak oszacować wpływ tego porozumienia na globalną gospodarkę. Teza artykułu głosi, że umowa o wolnym handlu może zmniejszyć protekcjonizm handlowy i w długoterminowej perspektywie przynieść stronom dynamicznej grupy handlowej większe korzyści gospodarcze niż protekcjonizm. Metodologia badań polega na wykorzystaniu analizy przekrojowej w oparciu o dane statystyczne i zebrane informacje, a także analizę polityki handlowej. Dodatkowo zastosowano krytyczną analizę literatury i analizę wnioskowania.

W wyniku badań stwierdzono, że umowa o wolnym handlu pomiędzy UE i Japonią może generować dodatkowy wzrost PKB na poziomie około 0,76 procent w UE i około 0,29 w Japonii rocznie przez następne dziesięć lat. Ponadto tworzy nowe miejsca pracy dla obu stron. Chociaż umowa o wolnym handlu UE z Japonią może spowodować pewne straty, szczególnie w gospodarkach Azji Wschodniej, takich jak Korea Południowa, Chiny i Tajwan, ich łączna kwota jest szacowana na bardzo niskim poziomie. W globalnej gospodarce umowa o wolnym handlu UE z Japonią może generować znacznie większe zyski niż straty. Oznacza to, że jeśli umowa ta wejdzie w życie będzie korzystna nie tylko dla jej sygnatariuszy - UE i Japonii - ale także dla całej gospodarki światowej.

Słowa kluczowe: mega-regionalna umowa o wolnym handlu, bariery handlowe, reguły handlu światowego, wolny handel, protekcjonizm 